\title{
Structure-function relationships of glycoprotein hormones; lessons from mutations and polymorphisms of the thyrotrophin and gonadotrophin subunit genes
}

\author{
Maria Alevizaki ${ }^{1}$, Ilpo Huhtaniemi ${ }^{2}$ \\ ${ }^{1}$ Endocrine Unit, Department of Medical Therapeutics, Athens University School of Medicine, Athens, Greece, and \\ ${ }^{2}$ Institute of Reproductive and Developmental Biology, Imperial College Medical Faculty, London, U.K.
}

\begin{abstract}
The pituitary glycoprotein hormones thyrotrophin (thyroid-stimulating hormone, TSH), lutrophin (luteinising hormone, LH) and follitrophin (follicle-stimulating hormone, FSH), as well as the placental choriongonadotrophin (human chorionic gonadotrophin, hCG) are composed of a common $\alpha$-subunit and a specific $\beta$-subunit, coupled by noncovalent interactions. Formation of $\alpha / \beta$ dimers is necessary for their biological function. Mutations and polymorphisms in the genes encoding these hormones are relatively rare, apparently because of their vital role in the regulation of reproductive and metabolic functions. However, a few genetic alterations in these genes have been identified and offer valuable, novel information about the structure-function relationships of the glycoprotein hormones. The purpose of this review is to present the known mutations and polymorphisms of the TSH, LH and FSH subunit genes and describe their functional consequences as causative factors of hypothyroidism and hypogonadism. Because genuinely inactivating TSH and gonadotrophin mutations are extremely rare, they are unlikely to be encountered in clinical practice. However, some of the polymorphisms are relatively common and because they may change the immunoreactivity of the hormone, they may result in aberrant laboratory findings.
\end{abstract}

Key words: Glycoprotein subunits, Gonadotrophins, Chorionic Gonadotrophin, Thyroid Stimulating Hormone, Central Hypothyroidism, Mutation.

\section{INTRODUCTION}

Four hormones belong to the family of glycoprotein hormones: the pituitary thyroid stimulating hormone (TSH), luteinising hormone (LH) and follicle-

Address correspondence and requests for reprints to: Maria Alevizaki, Endocrine Unit, Department of Medical Therapeutics, Athens University School of Medicine, 80 Vassilissis Sofias Avenue, 11528 Athens, Greece, FAX: 30107704143, E-mail: mani@otenet.gr

Received 01-06-02, Revised 25-07-02, Accepted 05-08-02 stimulating hormone (FSH), and the placental chorionic gonadotrophin (hCG). They are all composed of a 92- aminoacid common $\alpha$-subunit, which is linked through non-covalent interactions to the hormone specific $\beta$-subunit varying in length from 110 to 145 amino acids (Figure 1). In addition, carbohydrate side chains are attached to the peptide chains, two N-linked chains in the common $\alpha$-subunit, one in $\operatorname{TSH} \beta$, one in $\mathrm{LH} \beta$ and two in FSH $\beta$ (Figure 1). hCG is structurally and functionally very close to $\mathrm{LH} \beta$, and its main difference from the former is a 24 -amino acid C-termi- 


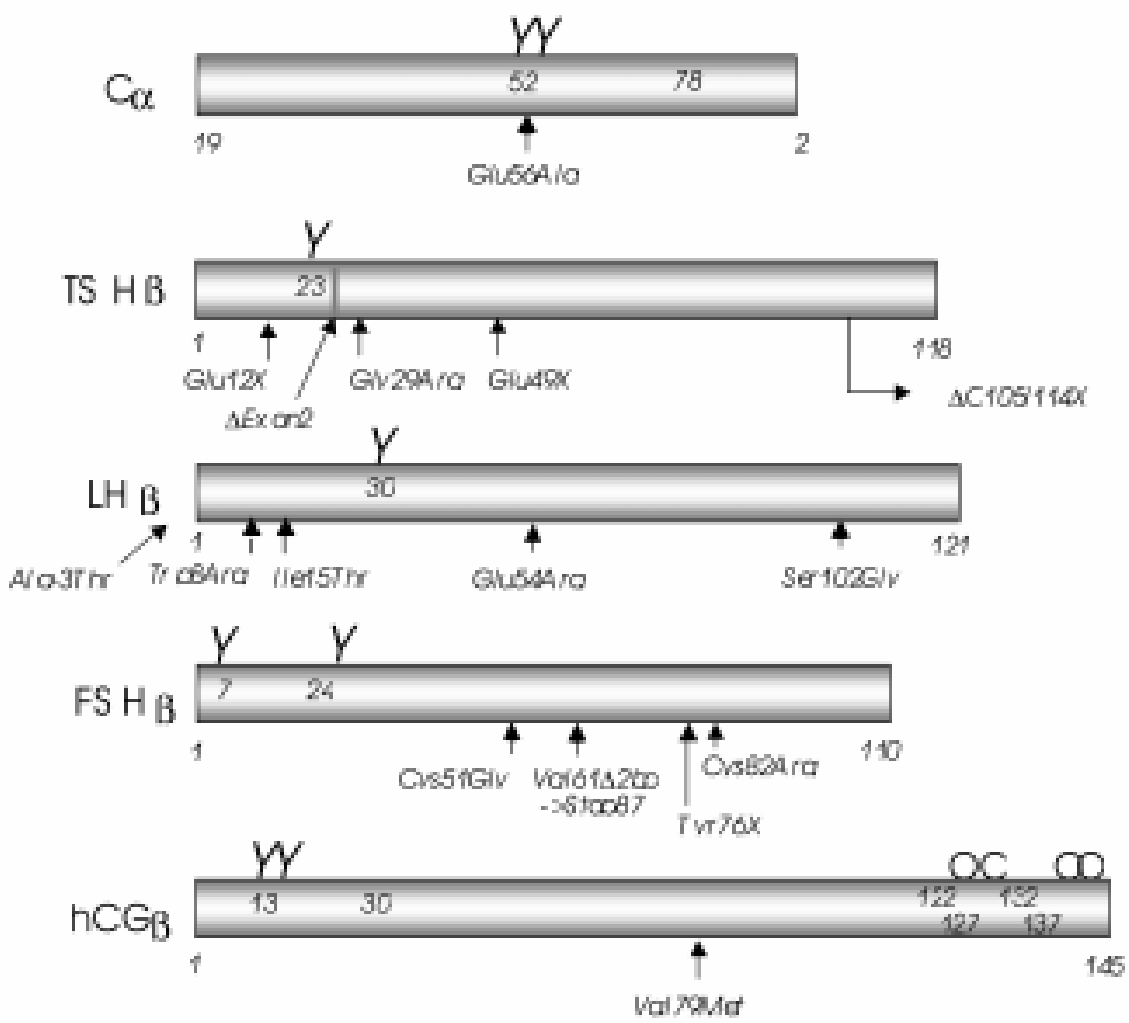

Figure 1. The currently known mutations and amino acid changing polymorphisms in the common a-subunit, TSH $\beta$, LH $\beta$, FSH $\beta$ and CG $\beta$ genes. For references and further details, see text.

nal extension. In addition to two N-linked carbohydrate side chains, the C-terminus of hCG is heavily glycosylated through four O-linked carbohydrate side chains.

The dimeric form of the glycoprotein hormones is mandatory for their biological activity and no convincing evidence exists about any biological activity of the monomeric subunits. The carbohydrates have a dual function, both increasing the circulatory half-time of the hormones and playing a role in signal transduction after the hormone has bound to its cognate receptor. Deglycosylated forms of the hormones, as has been shown in particular with $\mathrm{hCG}^{1}$, do bind with high affinity to the receptor, but are unable to trigger the signal transduction system.

Of the four glycoprotein hormones, the three-dimensional structure of hCG and FSH have been resolved $^{2,3}$. Molecular modeling, mutagenesis studies and structure comparisons between species have unraveled the critical structures that are necessary for proper tertiary structure, subunit dimerisation, receptor bind- ing activity and hormonal specificity of the hormones. One structural feature common in the gonadotrophin subunits is the cysteine knot structure they possess, which is essential for disulfide bonding and loop formation to establish functional motifs in the tertiary structure $^{4}$. All proteins with this basic structure are extracellular proteins interacting with specific receptors and/or other extracellular proteins. Transforming growth factor- $\beta$ (TGF $\beta)$ and platelet-derived growth factor (PDGF), for instance, belong to this family of proteins. Each subunit has an elongated shape with two $\beta$-hairpin loops on one side of the central cysteine knot and a long loop on the other side. The non-covalent interaction between the two subunits is stabilized by a segment of the $\beta$-subunit which extends like a 'seat-belt' around the $\alpha$-subunit, and is 'locked' by a disulfide bridge. The three-dimensional structure of FSH is presented in Figure 2.

One potential new member of the family of glycoprotein hormones, thyrostimulin, has recently been identified, based on genomic approaches ${ }^{5,6}$. It is a heterodimeric composed of an alpha-like (A2) and a beta- 
like (B5) subunit, which is localized in the human pituitary and has TSH-like activity. The two novel subunits have conserved cysteine residues similar to those found in the known alpha and beta subunits and have the characteristic cysteine knot structure of proteins related to TGF $\beta^{5,6}$.

\section{COMMON $\alpha$-SUBUNIT}

The common $\alpha$-subunit gene is localized on chromosome 6 and consists of 4 exons, of which the first one is non-coding. The mature protein is $92 \mathrm{a} / \mathrm{a}$ long. Several silent polymorphisms have been described in the common $\alpha$-subunit gene but none of them appears to affect the amino acid sequence ${ }^{7}$. Only one amino acid alteration has so far been detected in this gene, a Glu56Ala substitution, which was identified in the ectopically produced hCG of a human carcinoma ${ }^{8}$ (Figure 1). This was apparently a somatic mutation and the mutated $\alpha$-subunit displayed poor dimerisation with $\mathrm{LHb}$. The lack of proven germ line mutations in the $\alpha$-subunit could mean that, if such mutations exist, they must be lethal as they would lead to disrupted production of hCG, TSH, LH and FSH. On the other hand, mice with common $\alpha$-subunit knockout are viable ${ }^{9}$; this species does not produce chorionic gonadotrophin, indicating that some other mechanisms may be responsible for the functions of CG. All in all, it is unlikely that clearly inactivating mutations of the common $\alpha$-subunit will be detected in the future.

\section{hCG $\beta$ SUBUNIT}

Chorionic gonadotrophin and $\mathrm{LH} \beta$ chains are encoded by seven related genes forming a cluster on chromosome 19 and the genes of both LH $\beta$ and CG $\beta$ contain 3 exons. The mature CG $\beta$ protein is $145 \mathrm{a} / \mathrm{a}$ long. Several silent polymorphisms have been detected in the CG $\beta$ genes by restriction fragment length polymorphism analysis. Of the 6 CG $\beta$ genes in this cluster, the one most highly expressed, number 5 , seems to be highly conserved ${ }^{10}$. A single amino acid altering polymorphism, Val79Met, was detected in this gene $^{10}$ (Figure 1), and when it was co-expressed with the common $\alpha$-subunit gene, it displayed poor dimerisation with the $\alpha$-subunit. It was found at a frequency of $4.2 \%$ in healthy subjects but only in heterozygous form, which may mean that it affects hCG function so severely in homozygotes that they will not be viable. Hence, it is also unlikely that common mutations of the hCG $\beta$ subunit will be found.

\section{TSH $\beta$ SUBUNIT}

The TSH $\beta$ subunit gene is located on chromosome 1 and contains 3 exons, of which the first one is noncoding. The mature protein is $118 \mathrm{a} / \mathrm{a}$ long. Five mutations have been described in this gene, all leading to central hypothyroidism in their homozygous form

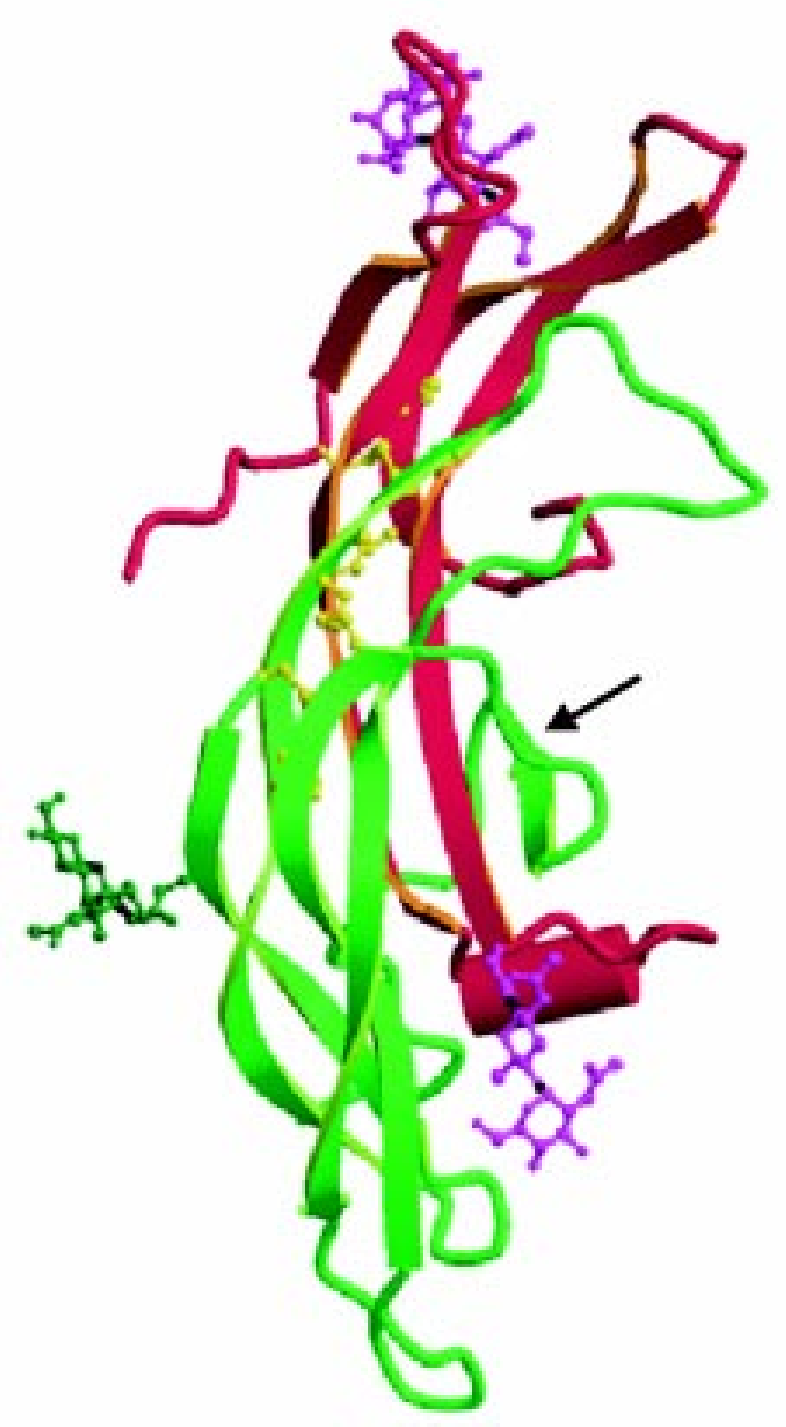

Figure 2. The three-dimensional structure of FSH. The $\alpha$-subunit is depicted with purple and $\beta$-subunit with green. Ball and stick models present the carbohydrate side chains and disulphide bonds. The 'seat-belt' of the $\beta$-subunit that extends around the $\alpha$-subunit is depicted with an arrow. (From Fox et al [2001] with permission). 
(Figure 1). The first one described in Japanese patients concerns codon 29 and is a Gly/Arg substitution $^{11}$. This region of the protein is very important for the association with the alpha subunit, so, although $\mathrm{TSH} \beta$ is produced, the mature glycoprotein dimer cannot be assembled. The other mutation described at the same time in Greece is a nonsense mutation and concerns the conversion of a glutamic acid in codon 12 to a stop codon leading to a severely truncated beta-subunit ${ }^{12}$. No TSH immunoreactivity was detected in the serum and patients presented with severe neonatal hypothyroidism.

Another nonsense mutation was more recently described on three unrelated families; this concerns codon 49 resulting in the conversion of glutamine to a stop codon ${ }^{13-15}$. TSH immunoreactivity was either normal or undetectable depending on the type of immunoassay used and the presence in the truncated protein of the epitopes recognized by the assay monoclonal antibodies. The subjects presented again with neonatal hypothyroidism and had extremely low detectable immunoreactive TSH. The truncated protein lacks the $\mathrm{C}$-terminal region containing several domains essential for proper dimerisation with the alpha subunit and binding to receptor (a/a 88-105 encompassing the "seat-belt" region as well as sequences 58-69 within the b-hairpin loop). It is possible that in these patients some, partial dimerisation with the alpha subunit occurred but it was not sufficient for proper activation of the TSH receptor.

A different mutation was described by MedeirosNeto et $\mathrm{al}^{16}$ concerning codon 105 . This was a frameshift deletion causing a substitution of a highly conserved Cys to Val and an altered 8 a/a sequence leading to a truncated protein of $114 \mathrm{a} / \mathrm{a}$. This mutation is believed to alter the conformation of the TSH molecule as one of the two disulphide bridges is disrupted. Patients carrying this mutation present with hypothyroidism in early neonatal life and have detectable TSH immunoreactivity, especially with competitive RIAs using polyclonal antibodies which recognize not only the heterodimer but also the circulating free $\operatorname{TSH} \beta$ mutant ${ }^{17}$. This mutation has been described in several kindreds ${ }^{17-19}$. It has been speculated that this altered TSH molecule may affect the constitutive activity of the unliganded TSH receptor as these patients present with severe hypothyroidism early in the neonatal period ${ }^{18}$.
The most recently found mutation in the $\operatorname{TSH} \beta$ gene concerns a donor splice site mutation in intron 2 which results in skipping of exon 2 of the gene. The putative product of the resulting transcript would be a severely truncated 25 a/a peptide with no biological activity. The patient presented with neonatal hypothyroidism and had extremely low levels of immunoreactive TSH in the serum ${ }^{20}$. In many cases with central hypothyroidism some peripheral thyroid hormone levels were measurable. In view of the recently discovered new glycoprotein, thyrostimulin ${ }^{6}$, some activation of the TSH receptor might be explained.

Regarding the TSH $\beta$ chain, only one common polymorphism has been described so far. This concerns the signal peptide, is an A14T substitution, is detected with a frequency of $1.8 \%$ and appears to be neutrall $^{20}$.

\section{LH $\beta$ SUBUNIT}

The LH $\beta$ gene also consists of 3 exons and the mature protein is $121 \mathrm{a} / \mathrm{a}$ long. Several polymorphisms with slight phenotypic effects, some of which fairly common, but only one inactivating mutation ${ }^{21}$, have been detected in the LH $\beta$ gene (Figure 1).

The mutation was detected in a male with delayed puberty at the age of 17 years. This patient had a family history of male infertility and manifested low serum testosterone levels accompanied by high levels of $\mathrm{LH}$ when the latter was measured by immunoassay. However, when LH was measured by in vitro bioassay, no LH bioactivity was detectable. Nevertheless, his testosterone production responded adequately to $\mathrm{LH} /$ hCG stimulation. Testicular biopsy revealed arrested spermatogenesis and absence of Leydig cells. Longterm hCG treatment produced testicular enlargement, virilisation and onset of spermatogenesis. Taken together, the findings suggested an inherited defect in the LH structure.

Sequencing of the LH $\beta$ gene of this hypogonadal man revealed a homozygous A-to-G missense mutation, bringing about a Glu54Arg mutation, and several heterozygous family members, including his mother, were identified. When the mutated $\mathrm{LH} \beta$ gene was coexpressed with normal $\alpha$-subunit in $\mathrm{CHO}$ cells, the $\alpha / \beta$ dimers formed were found to be totally devoid of biological activity because of inability to bind to the $\mathrm{LH}$ receptor in a radio-receptor assay. 
This rare case brings additional information to some aspects of the role of LH in male sexual differentiation and maturation. As this man carrying the homozygous LH $\beta$ mutation was normally masculinised at birth, it appears that pituitary LH is not absolutely necessary for stimulating testicular testosterone production in the fetal life. In fact, there is a body of information supporting the crucial role of hCG in the regulation of the fetal testis ${ }^{22}$. The situation after birth and after the elimination of hCG is different; pituitary LH becomes crucial for the postnatal differentiation and steroidogenic function of the Leydig cells, a phenomenon which explains the total lack of postnatal sexual development of the male. It is interesting that the male heterozygous family members, but not the females, had fertility problems. This may indicate a dosage effect with a higher degree of dependence of testicular function on adequate LH secretion in the male.

No females with inactivating $\mathrm{LH} \beta$ mutation have yet been detected. Their phenotype would most likely be similar to that of women with inactivating $\mathrm{LH}$ receptor mutation ${ }^{7}$, i.e. anovulatory infertility. The crucial role of LH in male and female fertility explains the rarity and self-limiting nature of this type of mutation, which would be rapidly eliminated from the genetic pool.

Several polymorphisms are known in the LH $\beta$ gene (Figure 1 and Table 1). One of them is common and its possible phenotypic effects have been widely investigated $^{23}$. The variant $(\mathrm{V}) \mathrm{LHb}$ allele carries two point mutations, each bringing about an amino acid change: Trp8Arg (TGG -> CGG) and Ile15Thr (ATC -> ACC). In addition, there are 8 additional point mutations in the first 600 nucleotides of the promoter of the $\mathrm{V}-\mathrm{LHb}$ allele ${ }^{24}$, indicative of altered promoter function on the variant allele. Studies on a recombinant form of $\mathrm{V}-\mathrm{LH}^{25}$ have shown that it is more potent than the wild-type (WT) LH at the receptor site, but its half-life in the circulation is shorter than that of WT-LH. Conversely, the V-LH $\beta$ promoter is more active than the WT sequence, possibly compensating for the faster elimination of the variant hormone from the circulation.

The V-LH $\beta$ allele shows a wide ethnic variability in its occurrence, with carrier frequency ranging from 0 in South India to more than 50\% amongst the Aboriginal Australians ${ }^{23}$. The frequency in Greece is $15 \%$
(Alevizaki \& Huhtaniemi, unpublished observation). Most of the observations so far made on phenotypic correlates of V-LH suggest that it represents a biologically weaker form of LH. These include slight but statistically significant alterations in parameters of ovarian steroidogenesis, female subfertility, slow tempo of puberty in boys, protection of obese women from symptomatic polycystic ovarian syndrome, obesity in ageing men, delayed occurrence of breast cancer in women and high frequency of cryptorchidism in boys born from overtime pregnancies (23; Huhtaniemi et al., unpublished observations). Although the findings seem like a mixed group of various phenotypes, they all are in keeping with apparently reduced bioactivity of V-LH. The point mutations alter the immunological epitope structure of V-LH, and therefore some commonly used immunoassay kits for LH do not detect it. It is therefore important for the clinician to be aware of this LH polymorphism since it can explain unexpectedly low levels of LH in some cases.

\section{FSH $\beta$ SUBUNIT}

The FSHb gene, also consisting of 3 exons, the first of which non-coding, is localised on chromosome 11. Only four women and three men with inactivating FSHb mutations have been detected so far (Figure 1 and Table 1). The first mutation, a homozygous 2-bp deletion in codon 61 (Val) was detected in a woman with primary amenorrhoea and infertility ${ }^{26}$. The mutation gave rise to a totally altered sequence between amino acids $61-87$, followed by a premature stop codon. These changes lead to inability of the protein to form the normal intramolecular disulfide bridges and the normal tertiary structure, and apparently accelerate its intracellular degradation, hamper its association with $\alpha$-subunit, and finally destroy its biological activity. The affected woman had normal adrenarche but no menarche or thelarche, due to missing onset of follicular development and granulosa cell oestrogen production in the absence of FSH. Treatment with FSH resulted in follicular maturation, ovulation and successful pregnancy. The other two women detected with inactivating $\mathrm{FSH} \beta$ mutation ${ }^{27,28}$ were phenotypically very similar to the first case and all these findings agree as regards the crucial role of FSH in follicular maturation and ovarian oestrogen production. Very recently, a third woman with partial breast development and primary amenorrhoea was described, 
Table 1. Currently known mutations and polymorphisms in human glycoprotein hormone subunit genes.

\begin{tabular}{|c|c|c|c|c|c|c|c|}
\hline Gene & Location & Type & Nucleotide change & Amino acid change & Phenotypes & Functional effect & Reference \\
\hline Common $\alpha$ & Exon 3 & Missense & $\mathrm{CA}^{239} \mathrm{G} \rightarrow \mathrm{CCG}$ & $\mathrm{Glu}^{56} \rightarrow$ Ala & Carcinoma & No association with $\beta$-subunit & Nishimura et al 1986 \\
\hline $\mathrm{TSH} \beta$ & Exon 2 & Missense & GGA $\rightarrow$ AGA & $\mathrm{Gly}^{29} \rightarrow \mathrm{Arg}$ & Central hypothyroidism & No association with $\alpha$-subunit & Hayashizaki et al 1990 \\
\hline $\mathrm{TSH} \beta$ & Exon 2 & Nonsense & $\mathrm{GAA} \rightarrow \mathrm{TAA}$ & $\mathrm{Glu}^{12} \rightarrow \mathrm{STOP}^{12}$ & Central hypothyroidism & Truncation of TSH $\beta$ subunit & Dacou-Voutetakis et al. 1990 \\
\hline $\mathrm{TSH} \beta$ & Exon2 & Frameshift & $\mathrm{C} 105 \Delta, 114 \mathrm{Stp}$ & $\begin{array}{l}8 \text { a.a. non-homologous } \\
\text { extension }\end{array}$ & Central hypothyroidism & $\begin{array}{l}\text { Truncation of TSH } \beta \text { subunit/ } \\
\text { no binding to receptor? }\end{array}$ & $\begin{array}{l}\text { Medeiros-Neto et al 1996, } \\
\text { Doeker et al 1998, } \\
\text { Bieberman et al 1999, } \\
\text { Heirichs et al } 2000 .\end{array}$ \\
\hline $\mathrm{TSH} \beta$ & Exon 3 & Nonsense & $\mathrm{C}^{654} \mathrm{AG} \rightarrow \mathrm{TAG}$ & $\mathrm{Gln}^{49} \rightarrow \mathrm{STOP}^{49}$ & Central hypothyroidism & Truncation of TSH $\beta$ subunit & $\begin{array}{l}\text { Sertedaki et al } 2000 \text {, } \\
\text { Bonomi et al 2001, } \\
\text { Vuissoz et al } 2001\end{array}$ \\
\hline $\mathrm{TSH} \beta$ & Intron 2 & $\begin{array}{l}\text { Donor/splice } \\
\text { site mutation }\end{array}$ & $\mathrm{G} \rightarrow \mathrm{A}(\mathrm{IVS} 2+5)$ & Skipping of exon 2 & Central hypothyroidism & $\begin{array}{l}\text { Truncated } 25 \mathrm{a} / \mathrm{a} \\
\text { functionless peptide }\end{array}$ & Pohlenz et al 2002 \\
\hline LH $\beta$ & Exon 3 & Missense & $\mathrm{CA}^{221} \mathrm{G} \rightarrow \mathrm{CGG}$ & $\mathrm{Gln}^{54} \rightarrow \mathrm{Arg}$ & Infertility, delayed puberty & No binding to receptor & Weiss et al. 1992 \\
\hline LH $\beta$ & Exon 2 & $\left.\begin{array}{l}2 \text { missense } \\
\text { mutations }\end{array}\right\}$ & $\begin{array}{l}\mathrm{T}^{82} \mathrm{GG} \rightarrow \mathrm{CGG} \\
\mathrm{AT}^{104} \mathrm{C} \rightarrow \mathrm{ACC}\end{array}$ & $\begin{array}{l}\operatorname{Trp}^{8} \rightarrow \operatorname{Arg} \\
\mathrm{Ile}^{15} \rightarrow \text { Thr }\end{array}$ & $\begin{array}{l}\text { Slighty suppressed fertility } \\
\text { Association with PCOS? }\end{array}$ & $\begin{array}{l}\text { Increased in vitro bioactivity } \\
\text { Short half-life }\end{array}$ & $\begin{array}{l}\text { Pettersson et al } 1994 \\
\text { Furui et al. } 1994\end{array}$ \\
\hline $\mathrm{LH} \beta$ & Exon 3 & Missense & $\mathrm{A}^{1502} \mathrm{GT} \rightarrow \mathrm{GGT}$ & $\operatorname{Ser}^{102} \rightarrow$ Gly & Infertility & Not detected & Liao et al. 1998 \\
\hline LH $\beta$ & Exon 3 & Missense & $\mathrm{G}^{52} \mathrm{CA} \rightarrow \mathrm{ACA}$ & $\mathrm{Ala}^{-3} \rightarrow \mathrm{Thr}$ & Not studied & $\begin{array}{l}\text { Slight decrease in signal } \\
\text { transduction activity }\end{array}$ & Jiang et al. 2002 \\
\hline hCG $\beta$ & Exon 3 & Missense & $\mathrm{G}^{295} \mathrm{TG} \rightarrow \mathrm{ATG}$ & $\mathrm{Val}^{79} \mathrm{Met}$ & Not studied & $\begin{array}{l}\text { Insufficient assembly } \\
\text { with } \alpha \text {-subunit }\end{array}$ & Miller-Lindholm et al 1999 \\
\hline $\mathrm{FSH} \beta$ & Exon 3 & 2-bp deletion & $\mathrm{GTG} \rightarrow \mathrm{GX}^{236,237}$ & $\mathrm{Val}^{61} \rightarrow \mathrm{STOP}^{87}$ & $\begin{array}{l}\text { Prim. amenorrhea, } \\
\text { infertility }\end{array}$ & Truncated protein & Matthews et al 1993 \\
\hline $\mathrm{FSH} \beta$ & Exon 3 & Missense & $\mathrm{T}^{206} \mathrm{GT} \rightarrow \mathrm{GGT}$ & $\mathrm{Cys}^{51} \rightarrow$ Gly & $\begin{array}{l}\text { Prim. amenorrhea, } \\
\text { infertility }\end{array}$ & Faulty tertiary structure of protein & Layman et al 1997 \\
\hline $\mathrm{FSH} \beta$ & Exon 3 & Missense & $\mathrm{T}^{298} \mathrm{GT} \rightarrow \mathrm{CGT}$ & $\mathrm{Cys}^{82} \rightarrow \mathrm{Arg}$ & $\begin{array}{l}\text { Azoospermia, absence } \\
\text { of FSH }\end{array}$ & Faulty tertiary structure of protein & Lindstedt et al 1998 \\
\hline $\mathrm{FSH} \beta$ & Exon 3 & Silent & $\mathrm{TAT}^{228} \rightarrow$ TAC & No change (Tyr) & $\begin{array}{l}\text { High FSH, association } \\
\text { with PCOS? }\end{array}$ & Not detected & Liao et al 1999 \\
\hline $\mathrm{FSH} \beta$ & Exon 3 & Nonsense & $\mathrm{TAC}^{282} \rightarrow \mathrm{TAA}$ & $\mathrm{Tyr}^{76} \rightarrow$ STOP & $\begin{array}{l}\text { Female: primary } \\
\text { amenorrhoea } \\
\text { Male: azoospermia }\end{array}$ & $\begin{array}{l}\text { Truncated protein, loss of } \\
\text { bioactivity }\end{array}$ & Layman et al 2002 \\
\hline
\end{tabular}

The nucleotide number was counted according to the translation start site (Fiddes and Talmadge 1984), the intronic sequences are excluded. 
and she had a Tyr76 STOP mutation in the FSH $\beta$ gene $^{29}$. The findings agree well with the observations in certain families from Finland, bearing the only so far known mutation that totally inactivates FSH receptor function ${ }^{30,31}$. Likewise, the phenotypes of FSH $\beta$ and FSH receptor knockout mice are in agreement as concerns the effects of inactivation of FSH/FSH receptor function in the human ${ }^{32-34}$.

Three men with inactivating FSH $\beta$ mutation have been described ${ }^{29,35,36}$. Each of them were azoospermic, which is in contrast to the reduced but existing spermatogenesis detected in men with inactivating FSH receptor mutation and knockout mouse models for FSH $\beta$ subunit and FSH receptor (see above). One explanation is that in two of the three $\operatorname{cases}^{35,36}$ the FSH $\beta$ mutations were specifically looked for in men with azoospermia, and it is not known whether they also exist in men with functional spermatogenesis. The men with inactivating FSH receptor mutation, in contrast, were detected because of their relationship with women with the mutation, and therefore there was no pre-selection according to the phenotype. It therefore appears that spermatogenesis is possible in the absence of FSH action, but in this situation its functional reserve is reduced leading to various degrees of suppression of spermatogenesis.

\section{CONCLUSIONS AND CLINICAL IMPLICATIONS}

Gonadotrophin and TSH $\beta$-subunit mutations are extremely rare and a clinician is not likely to find them. The importance of these cases has been that they have provided us with direct information about pathophysiological consequences of total lack of a specific hormone, and thereby elucidated normal and pathological function of the pituitary-thyroid and pituirary-gonadal axes. Interestingly, no mutations have been detected in the common $\alpha$-subunit, which would bring about elimination of hCG, TSH and the gonadotrophins, a condition possibly lethal for the fetus. Likewise, homozygous hCG $\beta$ mutations have not been found, a condition which would probably also be incompatible with successful pregnancy. As heterozygotes for mutations of the glycoprotein hormone subunits do not display specific phenotypes, it is in general possible that their inactivating mutations do exist. A clinician is likely not to find mutations in TSH or gonadotrophin subunit genes even in subjects with a suitable phenotype and family history. In these cas- es it is possible that the causative mutation affects some other genes crucial for the downstream events of glycoprotein hormone action. Such conditions have not yet been identified at the molecular level. Besides the rare mutations, there are more common polymorphisms, especially in the LH $\beta$ subunit, and they have some effects on hormonal function. For the clinician it is important to be aware of their existence because they may alter drastically the immunoreactivity of the hormone and the results of hormone assays.

\section{REFERENCES}

1. Dunkel L, Jia XC, Nishimori K, Boime I, Hsueh AJ, 1993 Deglycosylated human chorionic gonadotropin (hCG) antagonizes hCG stimulation of 3',5'-cyclic adenosine monophosphate accumulation through a noncompetitive interaction with recombinant human luteinizing hormone receptors. Endocrinology 132: 763-769.

2. Lapthorn AJ, Harris DC, Littlejohn A, Lustbader JW, Canfield RE, Machin KJ, Morgan FJ, Isaacs NW, 1994 Crystal structure of human chorionic gonadotropin. Nature 369: 455-461.

3. Fox KM, Dias JA, van Roey P, 2001 Three-dimensional structure of human follicle-stimulating hormone. Mol Endocrinol 15: 378-389.

4. Vitt UA, Hsu SY, Hsueh AJ, 2001 Evolution and classification of cysteine knot-containing hormones and related extracellular signaling molecules. Mol Endocrinol 15: 681694.

5. Hsu SY, Nakabayashi K, Bhalla A, 2002 Evolution of Glycoprotein Hormone subunit genes in bilateral matazoa: Identification of two novel human Glycoprotein Hormone subunit family genes, GPA2 and GPB5. Mol Endocrinol 16: $1538-1551$.

6. Nakabayashi K, Matsumi H, Bhalla A, Bae J, Mosselman S, Hsu SY, Hsueh AJW, 2002 Thyrostimulin, a heterodimer of two new human glycoprotein hormone subunits, activates the thyroid-stimulating hormone receptor. J Clin Invest 109: 1445-1452.

7. Themmen APN, Huhtaniemi IT, 2000 Mutations of gonadotropins and gonadotropin receptors: Elucidating the physiology and pathophysiology of pituitary-gonadal function. Endocr Rev 21: 551-583.

8. Nishimura R, Shin J, Ji I, Middaugh CR, Kruggel W, Lewis RV, Ji TH, 1986 A single amino acid substitution in an ectopic $\alpha$ subunit of a human carcinoma choriongonadotropin. J Biol Chem 261: 10475-10477.

9. Kendall SK, Samuelson LC, Saunders TL, Wood RI, Camper SA, 1995 Targeted disruption of the pituitary glycoprotein hormone alpha-subunit produces hypogonadal and hypothyroid mice. Genes Dev 9: 2007-2019.

10. Miller-Lindholm AK, Bedows E, Bartels CF, Ramey J, Maclin V, Ruddon RW, 1999 A naturally occurring genetic variant in the human chorionic gonadotropin-beta gene 5 is assembly inefficient. Endocrinology 140: 3496- 
3506.

11. Hayashizaki Y, Hiraoka Y, Tatsumi K, Hashimoto T, Furuyama J, Miyai K, Nishijo K, Matsuura M, Kohno H, Labbe A, Matsubara K, 1990 Deoxyribonucleic acid analyses of five families with familial inherited thyroid stimulating hormone deficiency. J Clin Endocrinol Metab 71: 792-796.

12. Dacou-Voutetakis C, Feltquate DM, Drakopoulou M, Kourides IA, Dracopoli NC, 1990 Familial hypothyroidism caused by a nonsense mutation in the thyroidstimulating hormone $\beta$-subunit gene. Am J Hum Genet 46: 988-993.

13. Sertedaki A, Papadimitriou A, Voutetakis A, Dracopoulou M, Dacou-Voutetakis C, 2000 Congenital hypothyroidism $(\mathrm{CH})$ caused by a new genetic defect of the thyrotropin (TSH) beta subunit gene associated with different hormonal derangement in the same sibship Horm Res 53: 11 (abstract).

14. Bonomi M, Proverbio MC, Weber G, Chiumello G, BeckPeccoz P, Persani L, 2001 Hyperplastic pituitary gland, high serum glycoprotein hormone alpha- subunit, and variable circulating thyrotropin (TSH) levels as hallmark of central hypothyroidism due to mutations of the TSH beta gene. J Clin Endocrinol Metab 86: 1600-1604.

15. Vuissoz JM, Deladoey J, Buyukgebiz A, Cemeroglu P, Gex G, Gallati S, Mullis PE, 2001 New autosomal recessive mutation of the TSH- $\beta$ subunit gene causing central isolated hypothyroidism, J Clin Endocrinol Metab 86: 4468-4471.

16. Medeiros-Neto G, Herodotou DT, Rajan S, Kommareddi S, de Lacerda L, Sandrini R, Bugosszewski MCS, Radovick S, Wondisford FE, 1996 A circulating, biologically inactive thyrotropin caused by a mutation in the $\beta$ subunit gene. J Clin Invest 97: 1250-1256.

17. Heinrichs C, Parma J, Scherberg NH, Delange F, Van Vliet G, Duprez L, Bourdoux P, Bergmann P, Vassart G, Refetoff S, 2000 Congenital central isolated hypothyroidism caused by a homozygous mutation in the TSH- $\beta$ subunit gene. Thyroid 10: 387-391.

18. Biebermann H, Liesenkotter KP, Emeis M, Oblanden M, Gruters A, 1999 Severe congenital hypothyroidism due to a homozygous mutation of the $\beta$ TSH gene. Pediatr Res 46: $170-173$.

19. Doeker BM, Pfäffle RW, Pohlenz J, Andler W, 1998 Congenital central hypothyroidism due to a homozygous mutation in the thyrotropin $\beta$-subunit gene follows an autosomal recessive inheritance. J Clin Endocrinol Metab 83: $1762-1765$.

20. Pohlenz J, Dumitrescu A, Aumann U, Koch G, Melchior R, Prawitt D, Refetoff S, 2002 Congenital secondary hypothyroidism caused by exon skipping due to a homozygous donor splice site mutation in the $\mathrm{TSH}\{$ beta $\}$ subunit gene. J Clin Endocrinol Metab 87: 336-339.

21. Weiss J, Axelrod L, Whitcomb RW, Harris PE, Crowley WF, Jameson JL, 1992 Hypogonadism caused by a single amino acid substitution in the beta subunit of luteinizing hormone. N Engl J Med 326: 179-183.

22. Huhtaniemi I, 1994 Fetal testis-a very special endocrine organ. Eur J Endocrinol 130: 25-31.

23. Lamminen T, Huhtaniemi I, 2001 A common genetic variant of luteinizing hormone; relation to normal and aberrant pituitary-gonadal function. Eur J Pharmacol 414: 17.

24. Jiang M, Pakarinen P, Zhang FP, El-Hefnawy T, Koskimies P, Pettersson K, Huhtaniemi I, 1999 A common polymorphic allele of the human luteinizing hormone betasubunit gene: additional mutations and differential function of the promoter sequence. Hum Mol Genet 8: 20372046.

25. Manna PR, Joshi L, Reinhold VN, Aubert ML, Suganuma N, Pettersson K, Huhtaniemi I, 2002 Synthesis, purification, and structural and functional characterization of recombinant form of a common genetic variant of human luteinizing hormone. Hum Mol Genet 11: 301-315.

26. Matthews CH, Borgato S, Beck-Peccoz P, Adams M, Tone Y, Gambino G, Casagrande S, Tedeschini G, Benedetti A, Chatterjee VK, 1993 Primary amenorrhoea and infertility due to a mutation in the beta-subunit of follicle-stimulating hormone. Nat Genet 5: 83-86.

27. Layman LC, Lee EJ, Peak DB, Namnoum AB, Vu KV, van Lingen BL, Gray MR, McDonough PG, Reindollar RH, Jameson JL,1997 Delayed puberty and hypogonadism caused by mutations in the follicle-stimulating hormone beta-subunit gene. N Engl J Med 337: 607-611.

28. Matthews C, Chatterjee VK, 1997 Isolated deficiency of follicle-stimulating hormone re-revisited. N Engl J Med 337: 642.

29. Layman LC, Porto ALA, Xie J, Casulari Roxo da Motta LA, Casulari DaMotta LD, Weiser W, Sluss PM, 2002 $\mathrm{FSH} \beta$ gene mutations in a female with partial breast development and a male sibling with normal puberty and azoospermia. J Clin Endocrinol Metab 87: 3702-3707.

30. Aittomäki K, Dieguez Lucena JL, Pakarinen P, Sistonen P, Tapanainen J, Gromoll J, Kaskikari R, Sankila E-M, Lehväslaiho H, Reyes Engel A, Nieschlag E, Huhtaniemi I, de la Chapelle A, 1995 Mutation in the follicle-stimulating hormone receptor gene causes hereditary hypergonadotropic ovarian failure. Cell 82: 959-968.

31. Tapanainen JS, Aittomäki K, Min J, Vaskivuo T, Huhtaniemi IT, 1997 Men homozygous for an inactivating mutation of the follicle-stimulating hormone (FSH) receptor gene present variable suppression of spermatogenesis and fertility. Nat Genet 15: 205-206.

32. Kumar TR, Wang Y, Lu N, Matzuk MM, 1997 Follicle stimulating hormone is required for ovarian follicle maturation but not male fertility. Nat Genet 15: 201-204.

33. Dierich A, Sairam MR, Monaco L, Fimia GM, Gansmuller A, LeMeur M, Sassone-Corsi P, 1998 Impairing folliclestimulating hormone (FSH) signaling in vivo: targeted disruption of the FSH receptor leads to aberrant gametogenesis and hormonal imbalance. Proc Natl Acad Sci U S A 95: 13612-13617.

34. Abel MH, Wootton AN, Wilkins V, Huhtaniemi I, Knight P, Charlton HM, 2000 The effect of a null mutation in the FSH receptor gene on mouse reproduction. Endocrinology 141: 1795-1803. 
35. Lindstedt G, Nyström E, Matthews C, Ernest I, Janson PO, Chatterjee K, 1998 Follitropin (FSH) deficiency in an infertile male due to FSHbeta gene mutation. A syndrome of normal puberty and virilization but underdeveloped testicles with azoospermia, low FSH but high lutropin and normal serum testosterone concentrations. Clin Chem Lab Med 36: 663-665.

36. Phillip M, Arbelle J, Segev Y, Parvari R, 1998 Male hypogonadism due to a mutation in the gene for the $\beta$-subunit of follicle-stimulating hormone. N Engl J Med 338: 1729-1732.

37. Pettersson K, Mäkelä MM, Dahlén P, Lamminen T, Huoponen K, Huhtaniemi I, 1994 Genetic polymorphism found in the $\mathrm{LH} \beta$ gene of an immunologically anomalous variant of human luteinizing hormone. Eur J Endocrinol 130: 65.

38. Furui K, Suganuma N, Tsukahara S, Asada Y, Kikkawa F, Tanaka M, Ozawa T, Tomoda Y, 1994 Identification of two point mutations in the gene coding luteinizing hormone ( $\mathrm{LH}$ ) beta-subunit, associated with immunologically anomalous LH variants. J Clin Endocrinol Metab 78: 107-113.

39. Liao WX, Roy AC, Chan C, Arulkumaran S, Ratnam SS, 1998 A new molecular variant of luteinizing hormone associated with female infertility. Fertil Steril 69: 102-106.

40. Liao WX, Tong Y, Roy AC, Ng SC, 1999 New AccI polymorphism in the follicle-stimulating hormone beta-subunit gene and its prevalence in three Southeast Asian populations. Hum Hered 49: 181-182.

41. Jiang M, Lamminen T, Pakarinen P, Hellman J, Manna P, Herrera RJ, Huhtaniemi I, 2002 A novel Ala(-3)Thr mutation in the signal peptide of human luteinizing hormone beta-subunit: potentiation of the inositol phosphate signalling pathway and attenuation of the adenylate cyclase pathway by recombinant variant hormone. Mol Hum Reprod 8(3): 201-12. 